\title{
Left atrial and left atrial appendage functional recovery after cardioversion in patients with recent atrial fibrillation: Serial echocardiographic study
}

\author{
Ahmed S. Ammar, Islam Elsherbiny, Ibtesam I. El-Dosouky, \\ Khaled Abd El Salam, Mohamed Abd El Hamid, Wael Khalil, Mas Ammar \\ Cardiology Department, Faculty of Medicine, Zagazig University, Egypt
}

\begin{abstract}
Background: The aim of this study is to point out timing of left atrium and its appendage functional recovery after cardioversion $(C V)$ in recent onset atrial fibrillation $(A F)$.

Methods: Fifty patients; 27 within 48-h (group I) and 23 after 48-h (group II), of AF onset, who had successful CV underwent transthoracic echocardiography (TTE), before and immediately after $C V$, then 15, 30 and 90 days later. Transesophageal echocardiography (TEE) was performed for group II before and for all patients immediately after CV and 1 month later. Mitral peak A velocity and left atrial (LA) reversal (Ar) velocity, tissue Doppler imaging (TDI) of septal mitral annular velocity (A1) and LA free wall velocity (A3) were recorded. Absence or peak $A$ velocity $<50 \mathrm{~cm} / \mathrm{s}$ was taken as a cut off value for atrial stunning. Intra-atrial conduction time (IACT) was measured. LA appendage late emptying (LAALE) velocity was measured by TEE-pulsed TDI of LA appendage.
\end{abstract}

Results: Post CV, all group II and 34\% of group I experienced stunning. In both groups, peak $A, A r, A 1, A 3$ and LAALE velocities increased $(p=0.000)$, while IACT decreased $(p=0.000)$ progressively over time. Partial recovery occurred after 15 and 30 days, while full recovery occurred 30 and 90 days post CV in groups I and II, respectively. IACT1 and IACT2 correlated with LA diameter ( $r=0.2778$ and $r=0.227$, respectively, $p<0.01)$.

Conclusions: Stunning and functional recovery of the LA and its appendage are strongly determined by the duration being in AF. Serial IACT by TDI was a good new parameter for detection of functional recovery of LA and LA appendage. (Cardiol J 2015; 22, 6: 699-707)

Key words: atrial fibrillation, atrial stunning, left atrial appendage function, left atrial function

\section{Introduction}

Successful cardioversion of atrial fibrillation (AF) usually results in left atrial (LA) and LA appendage (LAA) stunning that may last up to a few weeks, observed after all methods of cardioversion (CV). It is responsible for the increased incidence of thrombus formation and embolic events after CV, despite restoration of sinus rhythm [1].

Both, mitral A-wave velocity and LA emptying fraction (among other parameters) are derived by conventional transthoracic echocardiography (TTE) to evaluate the contractile function of the LA. Tissue Doppler imaging (TDI) can provide

Address for correspondence: Ibtesam Ibrahim El-Dosouky, MD, Lecturer of Cardiology. Cardiology Department, Faculty of Medicine, Zagazig University, 44519, Egypt, tel: +20506092608, e-mail: ibtesamaldosoky@yahoo.com 
other parameters of LA function such as A' velocity at different segments of the atria and intra-atrial conduction time (IACT) [2].

Transesophageal echocardiography (TEE) remains a semi-invasive procedure, limiting its serial application as a screening tool. Therefore, it is desirable to obtain information regarding LAA function by TTE [3]. Evaluation of the LA wall using pulsed TDI is feasible and reproducible. TDI provides a useful method in the assessment of LA conduction times [4]. The mitral annular velocities, obtained by transthoracic TDI are useful predictors for LA dysfunction and thrombus formation [5].

Aim of the study is to point out timing of LA and LAA functional recovery after $\mathrm{CV}$ in recent onset $\mathrm{AF}$.

\section{Methods}

Fifty consecutive patients with recent onset non-valvular $\mathrm{AF}$ who underwent successful $\mathrm{CV}$ to sinus rhythm were enrolled in the study to be followed up for 3 months, after exclusion of those with chronic AF, valvular heart disease, reversible causes of $\mathrm{AF}$, patients with liver impairment and structural heart disease and those with LA and/or LAA thrombus in initial TEE.

The patients were divided into two groups: Group I -27 patients with recent AF (within $48 \mathrm{~h}$ ) and underwent successful CV and maintained sinus rhythm; Group II -23 patients with recent onset AF (after $48 \mathrm{~h}$ ) and underwent successful CV and maintained sinus rhythm.

Approval was obtained from the Ethics Committee of our Cardiology Department after approval of the Institutional Review Board.

After giving a written informed consent, all participants were subjected to the following:

- full history taking stressed on age, duration of AF, past history of hypertension, ischemia or diabetes;

- thorough clinical examination with stress on heart rate, blood pressure and signs of left ventricular $(\mathrm{LV})$ failure;

- resting 12-lead surface electrocardiography (ECG): to confirm rhythm and rate;

- TTE, by an (Hewlett Pakard SONOS 5500) echo-set and 2.5-MHz transducers were used for imaging and Doppler studies. Patients were examined in the left lateral decubitus position after resting for $30 \mathrm{~min}$, every patient was examined: before $\mathrm{CV}$, immediately after (average 1 day), 15 days, 1 month, and 3 months after $\mathrm{CV}$. The following measurements were taken according to the recommendations of the American Society of Echocardiography and averaged from 3 cardiac cycles; ECG was obtained simultaneously.

Pulsed wave (PW) Doppler study. In the apical 4-chamber view, the following measurements were recorded.

Peak transmitral A wave velocity. The sample volume was positioned at the tips of the mitral valve leaflets, absence or peak A wave velocity less than $50 \mathrm{~ms}$ is taken as a cut off value denoting atrial stunning after CV [6].

Pulmonary venous flow pattern. The sample volume was positioned in the right upper pulmonary vein. The atrial reversal Ar velocity was measured. Two-dimensional (2D) echocardiography: To assess the LV function: Using modified Simpson's rule. LA diameter was also measured. TDI: Tissue Doppler echocardiography was performed by adjusting the spectral pulsed Doppler signal filters until a Nyquist limit of $15-20 \mathrm{~cm} / \mathrm{s}$, using the minimal optimal gain, monitor flow velocity was adjusted to $50-100 \mathrm{~mm} / \mathrm{s}$ to optimize the images of the myocardial velocity to measure the following:

Mitral annular velocities were measured from the apical 4-chamber view with the pulsed wave sample volume placed at septal (A1) and lateral (A2) mitral annular tissues.

IACT is the total duration of electrical activity of the LA in 1 cardiac cycle (the time between right atrial and LA activation). It was measured from the onset of $\mathrm{P}$ wave in ECG to the onset of $\mathrm{A}^{\prime}$ wave (PA) at both septal (IACT1) and lateral (IACT2) aspects of mitral annulus.

TEE was conducted using the same machine equipped with multi-plane transesophageal probe $(5 \mathrm{mHz})$. Images were taken before $\mathrm{CV}$ for patients with recent AF more than $48 \mathrm{~h}$ and for all patients; immediately after, and then 1 month later. To visualize the LAA from the mid-esophageal position, the angle providing the longest apex to orifice length was used for pulsed Doppler analysis, typically between 45 and 90 . A $4 \mathrm{~mm}$ sample volume was positioned $1 \mathrm{~cm}$ from the LAA orifice. Pulsed Doppler was used to measure the LAA flow and LAA late emptying (LAALE) velocities. In the TDI records, the first positive wave after the $\mathrm{P}$ wave (in ECG) was accepted as LAALE.

LA spontaneous echo contrast severity, graded on a scale of $0-4$.

Off-line assessment of 2D, Doppler, TDI and TEE images was performed by 2 investigators who were blinded to clinical data; the assessment was 
Table 1. Patients' characteristics.

\begin{tabular}{lccc}
\hline Variables & $\begin{array}{c}\text { Group I: CV before } 48 \mathrm{~h} \\
(\mathbf{n}=\mathbf{2 7})\end{array}$ & $\begin{array}{c}\text { Group II: } \mathbf{C V} \text { after } \mathbf{4 8} \mathbf{~ h} \\
(\mathbf{n}=\mathbf{2 3})\end{array}$ & $\mathbf{P}$ \\
\hline Age [years] & $43.07 \pm 4.22$ & $54.17 \pm 3.44$ & 0.125 \\
Gender: & & & 0.67 \\
$\quad$ Male & $18(66.7 \%)$ & $14(60.9 \%)$ & \\
$\quad$ Female & $9(33.3 \%)$ & $9(39.1 \%)$ & \\
Smokers & $7(26 \%)$ & $12(52.2 \%)$ & 0.05 \\
Body mass index & $28.15 \pm 3.58$ & $32.9 \pm 5.03$ & 0.001 \\
AF duration [h] & $8.52 \pm 3.04$ & $71.3 \pm 12.7$ & 0.000 \\
Electrical CV & $12(44.4 \%)$ & $12(52.2 \%)$ & 0.809 \\
Pharmacological CV & $15(55.6 \%)$ & $11(47.8 \%)$ & 0.765 \\
Amiodarone & $9(33.3 \%)$ & $6(26.1 \%)$ & 0.821 \\
Propafenone & $6(22.2 \%)$ & $5(21.7 \%)$ & 0.809 \\
\hline
\end{tabular}

$\mathrm{AF}$ - atrial fibrillation; $\mathrm{CV}$ - cardioversion; $\mathrm{p}>0.05$ indicates non-significance, $\mathrm{p}<0.05$ indicates significance and $\mathrm{p}<0.01$ indicates high significance

performed in 2 separate occasions for each of the investigators.

Electrical or pharmacological CV. The cases were selected for treatment designed to restore and maintain normal sinus rhythm according to the ACC/AHA/HRS guidelines [7].

Direct current cardioversion. Synchronized $\mathrm{CV}$ was performed during deep sedation with intravenous midazolam delivering a stepwise sequence of biphasic shocks as follows: first attempt at 100 Joules $(\mathrm{J})$; if failed a second one at $150 \mathrm{~J}$; if failed a third at $200 \mathrm{~J}$; if failed a final of $200 \mathrm{~J}$, with its failure considered an unsuccessful attempt. Patients who were cardioverted are maintained on amiodarone at a dose of $800 \mathrm{mg}$ per day in divided dose until $10 \mathrm{~g}$ total, then $200 \mathrm{mg}$ per day as maintenance.

Pharmacological CV: Patients with recent-onset $\mathrm{AF}$ without contraindications for the propafenone or amiodarone were treated either with:

- oral propafenone $(600 \mathrm{mg}$ for the first $24 \mathrm{~h}$ and if necessary a repeated dose of $300 \mathrm{mg}$ for $24 \mathrm{~h}$ ) then 450 to $900 \mathrm{mg}$ daily oral dose for maintenance of sinus rhythm or;

- amiodarone (intravenous) 5 to $7 \mathrm{mg} / \mathrm{kg}$ over 30 to $60 \mathrm{~min}$, then 1.2 to $1.8 \mathrm{~g}$ per day continuous IV until $10 \mathrm{~g}$ total, then 200 to $400 \mathrm{mg}$ per day oral maintenance.

\section{Statistical analysis}

All data were analyzed using SPSS 16 (SPSS, Inc. Chicago, IL, USA). Results were presented as mean value \pm standard deviation for continuous variables and as frequency (\%) for categorical vari- ables. Means were compared using independent t-test. Categorical data were compared using $\chi^{2}$ test, for repeated measures one way (ANOVA) was performed to estimate within patient changes for detection of LA and LAA stunning and functional recovery in the follow-up. Pearson correlations between variables were made. Determination of cut off values with associated sensitivity and specificity was performed using the receiver operating characteristics analysis.

\section{Results}

Our patients were divided into two groups, group I (AF cardioverted within $48 \mathrm{~h}$ ): included 27 patients; 18 males and 9 females with mean age $43.07 \pm 4.22$ years; group II (AF cardioverted after $48 \mathrm{~h}$ ) included 23 patients; 14 males and 9 females with mean age $54.17 \pm 3.44$ years, incidence of smoking was more in group II - $12(52.2 \%)$ vs. $7(26 \%)$ in group I with a statistically significant difference $(\mathrm{p}=0.05$ and so group II has higher body mass index $28.15 \pm 3.58$ vs. $32.9 \pm 5.03$ with a statistically significant difference $(\mathrm{p}=0.01)$, as in Table 1.

The serial changes in the different echocardiographic parameters as shown in Table 2, were as follows: the difference of serial A wave velocity of transmitral flow between groups was statistically significant $(\mathrm{p}=0.000)$. A wave increased significantly in a progressively linear trend over time from $50.33 \pm 5.57 \mathrm{~cm} / \mathrm{s}$ to full increase at 1 month $-62.66 \pm 3.1 \mathrm{~cm} / \mathrm{s}$ in group I and from 29.6 $\pm 4.85 \mathrm{~cm} / \mathrm{s}$ to $59.6 \pm 3.5 \mathrm{~cm} / \mathrm{s}$ after 3 months in 
Cardiology Journal 2015, Vol. 22, No. 6

Table 2. Serial echocardiographic parameters.

\begin{tabular}{|c|c|c|c|}
\hline Variables & $\begin{array}{c}\text { Group I }(n=27) \\
\text { Mean } \pm \text { SD }\end{array}$ & $\begin{array}{c}\text { Group II }(n=23) \\
\text { Mean } \pm \text { SD }\end{array}$ & $\mathbf{P}$ \\
\hline $\begin{array}{l}\text { Left ventricular ejection fraction [\%] } \\
\text { Immediately after } \\
\text { After } 15 \text { days } \\
\text { After } 1 \text { month } \\
\text { After } 3 \text { months }\end{array}$ & $\begin{array}{l}61.65 \pm 2.44 \\
61.65 \pm 2.44 \\
61.96 \pm 2.34 \\
61.65 \pm 2.44\end{array}$ & $\begin{array}{l}58.74 \pm 2.11 \\
58.82 \pm 1.99 \\
59.08 \pm 2.06 \\
59.13 \pm 2.02\end{array}$ & 0.000 \\
\hline $\begin{array}{l}\text { LA diameter [mm] } \\
\text { Immediately after } \\
\text { After } 15 \text { days } \\
\text { After } 1 \text { month } \\
\text { After } 3 \text { months }\end{array}$ & $\begin{array}{c}35.56 \pm 2.31 \\
35.56 \pm 2.31 \\
34.81 \pm 2.32 \\
34.8 \pm 2.32\end{array}$ & $\begin{array}{c}39.30 \pm 1.79 \\
39.30 \pm 1.79 \\
39.30 \pm 1.79 \\
38.3 \pm 1.79\end{array}$ & 0.000 \\
\hline $\begin{array}{l}\text { A wave velocity after } \mathbf{C V} \text { [cm/s] } \\
\text { Immediately after } \\
\text { After } 15 \text { days } \\
\text { After } 1 \text { month } \\
\text { After } 3 \text { months }\end{array}$ & $\begin{array}{c}50.33 \pm 5.57 \\
57.40 \pm 3.68 \\
62.66 \pm 3.1 \\
62.66 \pm 3.14\end{array}$ & $\begin{array}{l}29.6 \pm 4.85 \\
41.47 \pm 2.98 \\
52.56 \pm 2.57 \\
56.04 \pm 1.71\end{array}$ & 0.000 \\
\hline $\begin{array}{l}\text { PV Ar velocity after } \mathbf{C V} \text { [cm/s] } \\
\text { Immediately after } \\
\text { After } 15 \text { days } \\
\text { After } 1 \text { month } \\
\text { After } 3 \text { months }\end{array}$ & $\begin{array}{l}22.85 \pm 2.07 \\
25.33 \pm 2.21 \\
27.92 \pm 2.68 \\
27.92 \pm 2.63\end{array}$ & $\begin{array}{l}19.08 \pm 1.41 \\
22.04 \pm 1.58 \\
25 \pm 1.8 \\
27.21 \pm 1.34\end{array}$ & 0.000 \\
\hline $\begin{array}{l}\text { A1 wave velocity after } \mathbf{C V}[\mathbf{c m} / \mathbf{s}] \\
\text { Immediately after } \\
\text { After } 15 \text { days } \\
\text { After } 1 \text { month } \\
\text { After } 3 \text { months }\end{array}$ & $\begin{array}{c}7.67 \pm 1.56 \\
8.68 \pm 1.22 \\
9.6 \pm 0.9 \\
9.6 \pm 0.9\end{array}$ & $\begin{array}{l}4.09 \pm 1.56 \\
5.65 \pm 0.93 \\
7.22 \pm 0.85 \\
8.46 \pm 0.54\end{array}$ & 0.000 \\
\hline $\begin{array}{l}\text { A3 wave velocity after } \mathbf{C V}[\mathbf{c m} / \mathbf{s}] \\
\text { Immediately after } \\
\text { After } 15 \text { days } \\
\text { After } 1 \text { month } \\
\text { After } 3 \text { months }\end{array}$ & $\begin{array}{c}8.36 \pm 1.36 \\
9.5 \pm 1.1 \\
10.46 \pm 0.98 \\
10.46 \pm 0.98\end{array}$ & $\begin{array}{l}4.17 \pm 0.78 \\
5.81 \pm 0.95 \\
7.38 \pm 0.97 \\
8.63 \pm 0.72\end{array}$ & 0.000 \\
\hline $\begin{array}{l}\text { IACT1 after } \mathbf{C V} \text { [ms] } \\
\text { Immediately after } \\
\text { After } 15 \text { days } \\
\text { After } 1 \text { month } \\
\text { After } 3 \text { months }\end{array}$ & $\begin{array}{l}96.3 \pm 7.52 \\
88.48 \pm 7.01 \\
80.52 \pm 8.34 \\
80.52 \pm 8.31\end{array}$ & $\begin{array}{c}112.4 \pm 9.52 \\
104.21 \pm 7.7 \\
95.65 \pm 5.27 \\
90 \pm 4.4\end{array}$ & 0.000 \\
\hline $\begin{array}{l}\text { IACT2 after CV [ms] } \\
\text { Immediately after } \\
\text { After } 15 \text { days } \\
\text { After } 1 \text { month } \\
\text { After } 3 \text { months }\end{array}$ & $\begin{array}{c}96.44 \pm 6.68 \\
88.52 \pm 7 \\
79.78 \pm 8.36 \\
79.78 \pm 8.36\end{array}$ & $\begin{array}{c}111.74 \pm 24.01 \\
106.26 \pm 7.77 \\
97.08 \pm 5.42 \\
91.04 \pm 4.49\end{array}$ & 0.000 \\
\hline $\begin{array}{l}\text { LAA emptying velocity }[\mathbf{c m} / \mathbf{s}] \\
\text { Immediately after CV } \\
\text { After } 1 \text { month }\end{array}$ & $\begin{array}{c}38.74 \pm 2.7 \\
46.70 \pm 1.43\end{array}$ & $\begin{array}{l}19.56 \pm 2.84 \\
40.17 \pm 3.25\end{array}$ & 0.000 \\
\hline $\begin{array}{l}\text { LAA emptying velocity by TDI }[\mathbf{c m} / \mathbf{s}] \\
\text { Immediately after CV } \\
\text { After } 1 \text { month }\end{array}$ & $\begin{array}{c}9.94 \pm 1 \\
13.02 \pm 0.62\end{array}$ & $\begin{array}{l}4.51 \pm 0.62 \\
10.1 \pm 0.85\end{array}$ & 0.000 \\
\hline $\begin{array}{l}\text { Spontaneous echo contrast grading } \\
\text { Immediately } \\
\text { After } 1 \text { month }\end{array}$ & $\begin{array}{l}0 \\
0\end{array}$ & $\begin{array}{l}1.04 \pm 0.47 \\
0.02 \pm 0.14\end{array}$ & $\begin{array}{l}0.000 \\
0.566\end{array}$ \\
\hline
\end{tabular}

CV — cardioversion; LA — left atrial; LAA — left atrial appendage; A wave — peak late diastolic mitral flow; A1 — septal mitral annular A' (by tissue Doppler); $A 3$ - left atrial mid free wall A'; IACT1 - septal mitral annular intra-atrial conduction time; IACT2 - lateral mitral annular intra-atrial conduction time; PV Ar — pulmonary venous flow-left atrial flow reverse; TDI — tissue Doppler imaging 
group II. Pulmonary Ar velocity increased progressively in a linear trend over time from $22.85 \pm$ $\pm 2.07 \mathrm{~cm} / \mathrm{s}$ to full increase at 1 month $-27.92 \pm$ $\pm 2.68 \mathrm{~cm} / \mathrm{s}$ in group I and from $19.08 \pm 1.41 \mathrm{~cm} / \mathrm{s}$ to $27.21 \pm 1.34 \mathrm{~cm} / \mathrm{s}$ after 3 months in group II with a statistically significant difference between the groups $p=0.000$ ). The difference of serial septal mitral annular A' wave velocity, by tissue Doppler (A1) between groups was statistically significant $(\mathrm{p}=0.000)$. A1 wave increased significantly in a progressively linear trend over time from $7.67 \pm$ $\pm 1.56 \mathrm{~cm} / \mathrm{s}$ to full increase at 1 month $9.6 \pm 0.9 \mathrm{~cm} / \mathrm{s}$ in group I and from $4.09 \pm 0.87 \mathrm{~cm} / \mathrm{s}$ to $8.46 \pm$ $\pm 0.54 \mathrm{~cm} / \mathrm{s}$ after 3 months in group II. LA mid free wall A' (A2) velocity increased progressively in a linear trend over time from $8.36 \pm 1.36 \mathrm{~cm} / \mathrm{s}$ to full increase at 1 month $-10.46 \pm 0.98 \mathrm{~cm} / \mathrm{s}$ in group I and from $4.17 \pm 0.78 \mathrm{~cm} / \mathrm{s}$ to $8.63 \pm$ $\pm 0.72 \mathrm{~cm} / \mathrm{s}$ ) after 3 months in group II with a statistically significant difference between the groups $(p=0.000)$. The intra-atrial conduction time at septal and lateral aspects of the mitral valve (IACT1 and IACT2) decreased progressively in a linear trend over time from $96.3 \pm 7.52$ and $96.44 \pm 6.68 \mathrm{~ms}$, respectively, to full reduction at 1 month $-80.52 \pm 8.3$ and $79.78 \pm 8.36 \mathrm{~ms}$, respectively in group I and from $112.4 \pm 9.52$ and $111.74 \pm 24.01 \mathrm{~ms}$, respectively to $90 \pm 4.4$ and $91.04 \pm 4.49 \mathrm{~ms}$, respectively after 3 months in group II with a statistically significant difference between groups $(\mathrm{p}=0.000)$. Both LAA emptying Doppler and TDI estimated velocities increased significantly from $38.74 \pm 2.73$ and $9.94 \pm 1 \mathrm{~cm} / \mathrm{s}$, respectively immediately after $\mathrm{CV}$ to $46.70 \pm 1.43$ and $13.02 \pm \pm 0.62 \mathrm{~cm} / \mathrm{s}$, respectively at 1 month in group I, it decreased significantly immediately post $\mathrm{CV}$ to be $19.56 \pm 2.84$ and $4.51 \pm 0.62 \mathrm{~cm} / \mathrm{s}$, respectively and increased significantly to be $40.17 \pm$ \pm 3.25 and $10.1 \pm 0.85 \mathrm{~cm} / \mathrm{s}$, respectively at 1 month in group II, with a statistically significant difference between groups $(p=0.000)$.

LA diameter decreased progressively in a linear trend over time from $35.56 \pm 2.31 \mathrm{~mm}$ to full reduction at 1 month $-34.81 \pm 2.32 \mathrm{~mm}$ in group I and from $39.30 \pm 1.79 \mathrm{~mm}$ to $38.3 \pm 1.79 \mathrm{~mm}$ after 3 months in group II with a statistically significant difference between the groups $(p=0.000)$.

There was no spontaneous echo contrast (SEC) in group I either immediately after or after 1 month of CV, but it was found in group I (grade $1.04 \pm 0.47$ ) immediately after CV and improved by the end of $1^{\text {st }}$ month to be (grade $0.02 \pm 0.14$ ).

AF duration correlated negatively with: A wave velocity $(r=-0.888, p=0.000), A 1$ $(\mathrm{r}=-0.786, \mathrm{p}=0.000), \mathrm{A} 3(\mathrm{r}=-0.868, \mathrm{p}=0.000)$, pulmonary venous flow-LA flow reverse $(r=-0.712$, $\mathrm{p}=0.000)$, LAA emptying velocity $(\mathrm{r}=-0.962$, $\mathrm{p}=0.000)$ and LAA emptying velocity by tissue Doppler $(\mathrm{r}=-0.947, \mathrm{p}=0.000)$ and positively with: IACT1 $(r=0.708, p=0.000)$ and IACT2 $(r=0.474$, $\mathrm{p}=0.001)$.

LA diameter correlated significantly with $\operatorname{IACT} 1(\mathrm{r}=0.277, \mathrm{p}=0.000)$ and IACT2 $(\mathrm{r}=0.227$, $\mathrm{p}=0.001)$.

The increase of the A1 velocity to $8 \mathrm{~cm} / \mathrm{s}$ reflected a cut off value with a sensitivity of $93.9 \%$ and specificity of $41.2 \%(\mathrm{p}=0.002), \mathrm{A} 2$ at $8.5 \mathrm{~cm} / \mathrm{s}$ reflected a cut off value with a sensitivity of $87.9 \%$ and specificity of $41.2 \%(\mathrm{p}=0.019)$. The IACT at septal annular velocity (IACT1) at $98.5 \mathrm{~cm} / \mathrm{s}$ reflected a cut off value with a sensitivity of $72.7 \%$ and a specificity of $58.8 \%(\mathrm{p}=0.029)$, while the IACT at lateral annular velocity (IACT2) at $98.5 \mathrm{~cm} / \mathrm{s}$ reflected a cut off value with a sensitivity of $72.7 \%$, a specificity of $47.1 \%$ ( $\mathrm{p}=0.162$ ).LAA emptying velocity at a cut off value of $38.5 \mathrm{~cm} / \mathrm{s}$ had a sensitivity of $87.9 \%$ and specificity of $52.9 \%(\mathrm{p}=0.002)$, but by TDI at a velocity of $10 \mathrm{~cm} / \mathrm{s}$ it reflected a cut off value with a sensitivity of $87.9 \%$ and a specificity of $70.6 \%(\mathrm{p}=0.000)$ (Figs. 1-4).

\section{Discussion}

Mechanical dysfunction of the LA and/or LAA, called atrial stunning, develops after successful CV of $\mathrm{AF}$ or atrial flutter. Its prevalence varies from $38 \%$ to $80 \%$ in the previous studies [8]. In fact, atrial stunning is no more than a continuation of atrial remodeling that occurs during AF. It is characterized by progressive structural changes of the atria, especially with longer duration of arrhythmia [9]. Atrial stunning was defined as the presence of any of the following parameters: (1) Absence or peak velocity $<50 \mathrm{~cm} / \mathrm{s}$ of mitral inflow A-wave, (2) Recently developed of SEC or thrombus, or increase in severity of the already existing SEC, (3) LAA emptying velocity $<20 \mathrm{~cm} / \mathrm{s}$, and (4) Decrease of $20 \%$ in peak LAA emptying velocity after CV. After successful CV of AF, if the patient had at least one of above 4 parameters, they were described as having stunning [10].

Lack of effective atrial contractility can lead to hemodynamic changes, which may result in thrombus formation, with subsequent thromboembolic events [11].

Several investigators have evaluated the recovery of atrial function with restoration of sinus rhythm using invasive and non-invasive 


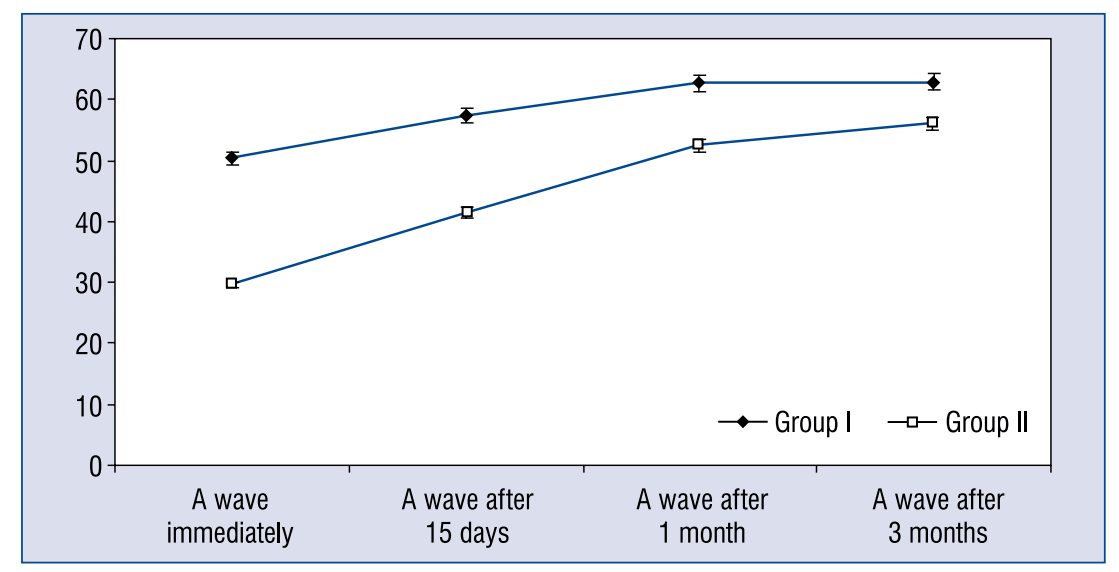

Figure 1. Serial changes of $A$ wave after cardioversion of atrial fibrillation.

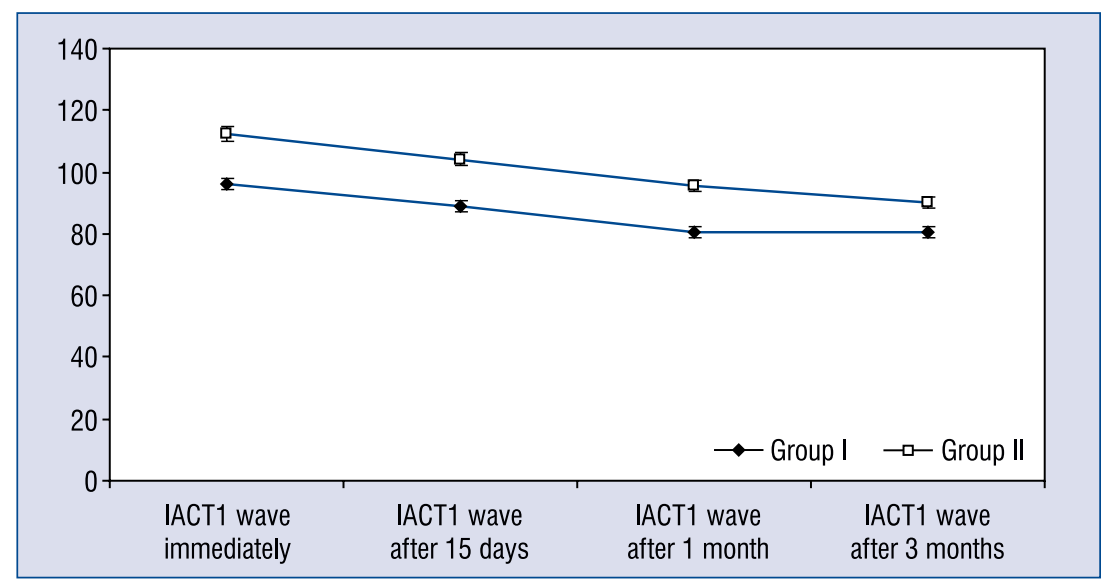

Figure 2. Serial changes of intra-atrial conduction time 1 (IACT1) after cardioversion of atrial fibrillation.

techniques, these studies confirmed the electromechanical dissociation of atrial recovery after successful CV [12] with a delay in the gradual improvement of the atrial mechanical function [13].

We investigated the serial echocardiographic parameters for detection of both stunning duration and timing of recovery of LA and LAA function post cardioversion of recent AF.

In our study, smoking and obesity were more prevalent among patients with longer duration of $\mathrm{AF}$ before $\mathrm{CV}$, which may be due to earlier presentation of non obese and non smokers as the LA is smaller and so pulmonary congestion and dyspnea, as an alarming sign, was presented earlier, in agreement with Gami et al. [14].

Firstly, we decided to follow-up the parameters of LA function immediately post CV (average 1 day). We found that the transmitral $\mathrm{A}$ wave and pulmonary venous flow (Ar) velocities were lower in patients cardioverted after $48 \mathrm{~h}$ (with longer duration being in AF), representing more stunning and in this group of patients they showed delayed recovery to be completed after 3 months, but complete recovery in group I after 1 month. Manning et al. [5], Ciolli et al. [15] and Dogan et al. [8] agreed with us. Only $34 \%$ of our patients (in group I) showed complete recovery of mechanical function immediately after CV similar to these in published reports (ranging from $38 \%$ to $80 \%$ ) [1] Harjai et al. [16] found that: many studies stated that recovery of effective mechanical function occurs in over $50 \%$ of patients 1 day after CV. Hyon et al. [17] found that: transmitral A velocity was still low $(34.9 \pm 19.5 \mathrm{~cm} / \mathrm{s})$ immediately after sinus conversion. Wożakowska-Kapłon et al. [18] and Boyd et al. [19] found that the maximum improvement in atrial contraction occurred in the first month after restoration of sinus rhythm. Atrial reversal flow 


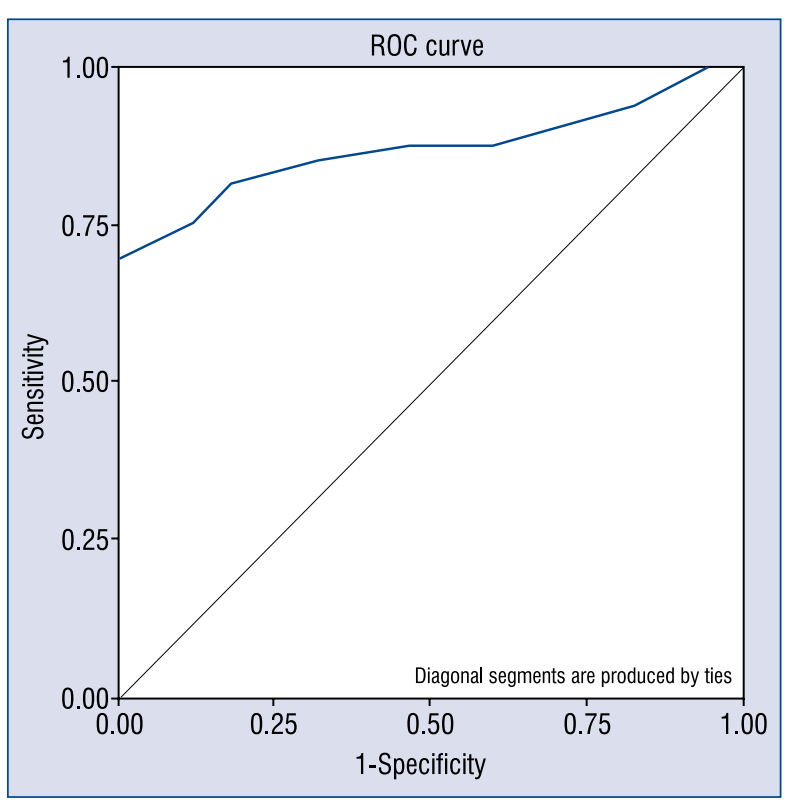

Figure 3. Receiver operating characteristics $(\mathrm{ROC})$ curve of left atrium appendage emptying velocity, velocity at cut off value of $38.5 \mathrm{~cm} / \mathrm{s}$ : had a sensitivity of $87.9 \%$, a specificity of $52.9 \%$, a positive predictive value of $78.4 \%$, and a negative predictive value of $69.2 \%(p=0.002)$.

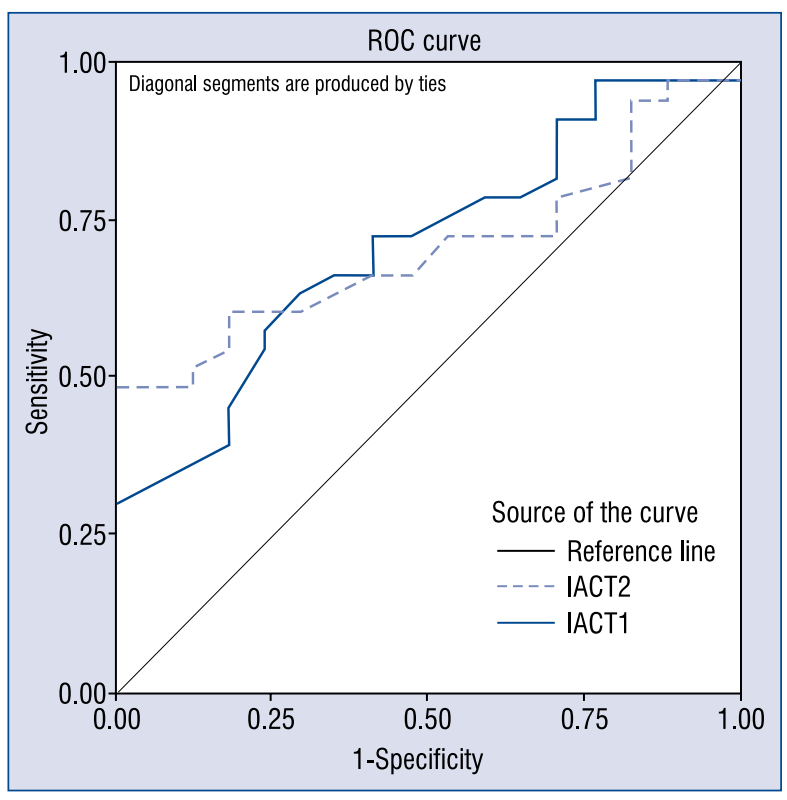

Figure 4. Receiver operating characteristics $(\mathrm{ROC})$ analysis of validity of serial intra-atrial conduction time 1 (IACT1) and 2 (IACT2) in detection of left atrium electromechanical recovery post cardioversion of recent atrial fibrillation.

represents transient reversal of flow in the pulmonary vein resulting from organized atrial activity. The return of atrial contraction has been shown to be delayed with a progressive increase in the atrial contribution to ventricular filling documented over the 3 months following successful CV [20]. Khan [21] estimated that duration of preceding $\mathrm{AF} /$ atrial flutter, atrial size, and underlying heart disease are determinants of the extent of atrial stunning, we found that LA diameter in group I was higher than that of group II.

We found that the mitral annular A (A1) wave velocity and the LA free wall velocity by, TDI, were lower in patients being longer in AF, and gradually increased to be full after 3 months but higher in patients cardioverted within $48 \mathrm{~h}$ and went rapidly to recovery to be full after 1 month only. We used it as it can provide a more accurate assessment of atrial function by measuring intrinsic atrial longitudinal contraction [21]. Boyd et al. [19] supported our results that TDI could be useful for serial follow-up of $\mathrm{LA}$ recovery after $\mathrm{AF} \mathrm{CV}$.

Our study showed that IACT, representing the atrial electromechanical interval, in serial echo, was shorter in group I, regained and stabilized in this group after 1 month, but longer and showed delayed recovery in group II. IACT showed significant correlation with $\mathrm{AF}$ duration as the other parameters used to estimate stunning and recovery of LA and LAA did, and showed significant correlation with the LA diameter. IACT may be considered a useful follow-up parameter for mechanical recovery (electrical-mechanical coupling) detection in patients after $\mathrm{CV}$ although our patients were on propafenone or amiodarone (which are accused to prolong the IACT) this factor was equally present in both groups. As previous studies showed that, LA electromechanical time was significantly prolonged in patients with recurring AF [22]. Omi et al. [23] found that: in paroxysmal AF group, these intervals were significantly longer than in the control group. This parameter is affected in patients with paroxysmal AF and should be useful for detecting atrial impairment related to paroxysmal AF. Acar et al. [24] found that: increased inter-atrial electromechanical delay might be related with an increased risk for AF.

We found that LAA emptying velocities by Doppler and by TDI, increased significantly over time in group I (but we had no idea about it before CV) and decreased significantly immediately post $\mathrm{CV}$ and increased significantly after 1 month in group II. Zapolski and Wysokiński [25] and Savontaus and Markku [26] estimated that all the atrial appendage Doppler velocity parameters were significantly reduced after the sinus rhythm restoration.

Agmon et al. [27] found that TEE is an invasive procedure; sequential TEE data assessing recovery 
of LAA function are limited. Significant improvement has been observed in LAA function within 7-30 days after $\mathrm{CV}$, although the determinants of the time-course of LAA recovery are incompletely defined.

\section{Limitations of the study}

The present study was limited by the small sample size. We selected non valvular patients.

\section{Conclusions}

Serial transthoracic IACT at medial and lateral mitral annulus, representing the atrial electromechanical interval, by TDI was a good new parameter for detection of functional recovery of LA and LAA. Also the longer the duration of $\mathrm{AF}$ before $\mathrm{CV}$ the delayed the recovery of LA and LAA mechanical function.

Clinical implications: These results may have important implications in guiding the appropriate duration of anticoagulant therapy after $\mathrm{CV}$ of recent $\mathrm{AF}$, as we can stop oral anticoagulant if LA and LAA functional recovery become full within 1 month in these cases, with respect to the $\mathrm{CHA}_{2} \mathrm{DS}_{2}$ -VASc score, that acknowledges the importance of age $\geq 75$ years as having additional weight as a single risk factor for stroke (denoted by a score of 2 points) and indicates that age is not a yes-no phenomenon because risk of stroke increases with age, particularly from 65 years of age on [28, 29].

Recommendation: We recommend serial estimation of the LAA empting velocities both by Doppler and TDI modalities by TTE, before and after $\mathrm{CV}$ for longer time. Prospective studies should be conducted on a larger group of patients who should be categorized into groups according to the underlying heart disease. The medication history must be kept in mind as some drugs can affect the IACT.

\section{Acknowledgments}

To all patients and colleagues in the cardiology department who helped us complete this work.

\section{Conflict of interest: None declared}

\section{References}

1. Mattioli AV1, Bonatti S, Melotti R, Mattioli G. Atrial stunning, inflammation and nutritional status after cardioversion from atrial fibrillation. Int J Cardiol, 2008; 129: 344-347.

2. Uslu N, Nurkalem Z, Orhan AL et al. Transthoracic echocardiographic predictors of the left atrial appendage contraction velocity in stroke patients with sinus rhythm. Tohoku J Exp Med, 2006; 208: 291-298.

3. Pérez-Paredes M, Gonzálvez M, Ruiz Ros JA et al. Assessment of left atrial wall velocities by pulsed wave tissue Doppler imaging. A new approach to the study of atrial function. Rev Esp Cardiol, 2004; 57: 1059-1065.

4. Deniz A, Sahiner L, Aytemir K et al. Tissue Doppler echocardiography can be a useful technique to evaluate atrial conduction time. Cardiol J, 2012; 19: 487-493.

5. Manning WJ, Silverman DI, Katz SE et al. Temporal dependence of the return of atrial mechanical function on the mode of cardioversion of atrial fibrillation to sinus rhythm. Am J Cardiol, 1995; 75: 624-626.

6. Climent V, Marín F, Monmeneu JV, García de Burgos F, Sogorb F. Atrial stunning as a predictor of early relapse into atrial fibrillation after cardiovertion. Int J Cardiol, 2006; 110: 427-428.

7. Wann LS, Curtis AB, January CT et al. 2011 ACCF/AHA/HRS focused update on the management of patients with atrial fibrillation (updating the 2006 guideline): a report of the American College of Cardiology Foundation/American Heart Association Task Force on Practice Guidelines. J Am Coll Cardiol, 2011; 57: 1330-1337.

8. Dogan A, Gedikli O, Ozaydin M, Acar G, Avsar A, Altinbas A. Mitral annular velocity by Doppler tissue imaging for the evaluation of atrial stunning after cardioversion of atrial fibrillation. Int J Cardiovasc Imaging, 2009; 25: 113-120.

9. Dagres N, Karatasakis G, Panou F et al. Pre-treatment with Irbesartan attenuates left atrial stunning after electrical cardioversion of atrial fibrillation. Eur Heart J, 2006; 27: 2062-2068.

10. Khan IA. Atrial stunning: basics, clinical considerations. Int J Cardiol, 2003; 92: 113-128.

11. Dabek J, Gasior Z, Monastyrska-Cup B, Jakubowski D. Cardioversion and atrial stunning. Pol Merk Lek, 2007; 22: 224-228.

12. Thomas L, Hoy M, Byth K, Schiller NB. The left atrial function index :a rhythm independent marker of atrial function. Eur J Echocardiogr, 2008; 9: 356-362.

13. Zhang Q, Yip GW, Yu CM. Approaching regional left atrial function by tissue Doppler velocity and strain imaging. Europace, 2008; 10 (suppl. 3): iii62-iii69.

14. Gami AS, Hodge DO, Herges RM et al. Obstructive sleep apnea, obesity, and the risk of incident atrial fibrillation. J Am Coll Cardiol, 2007; 49: 565-571.

15. Ciolli A, De Sisti A, Montenero AS, Sanna T, Lo Sardo G, Palamara A. Idiopathic atrial fibrillation of recent onset and atrial stunning: The echocardiographic evidence after pharmacological cardioversion. Cardiologia, 1998; 43: 1077-1082.

16. Harjai KJ, Mobarek SK, Cheirif J, Boulos LM, Murgo JP, Abi-Samra F. Clinical variables affecting recovery of left atrial mechanical function after cardioversion from atrial fibrillation. J Am Coll Cardiol, 1997; 30: 481-486.

17. Hyon MS, Lee SH, Cho SJ, Park SH, Kim MA. Electrical cardioversion of chrome non-valvular atrial fibrillation under transesophageal echocardiographic guidance. Korean Circ J, 1997; 27: 488-500.

18. Wożakowska-Kapłon B, Opolski G. Concomitant recovery of atrial mechanical and endocrine function after cardioversion in patients with persistent atrial fibrillation. J Am Coll Cardiol, 2003; 41: 1716-1720.

19. Boyd AC, Schiller NB, Ross DL, Thomas L. Segmental atrial contraction in patients restored to sinus rhythm after cardioversion for chronic atrial fibrillation: A colour Doppler tissue imaging study. Eur J Echocardiogr, 2008; 9: 12-17. 
20. Paraskevaidis IA, Theodorakis GN, Katritsis DG, Tsiapras DP, Livanis EG, Kremastinos DT. Pulmonary vein flow analysis by transesophageal echocardiography in patients with chronic atrial fibrillation 1 year follow-up after cardioversion. Eur Heart J, 1999; 20: 375-385.

21. Khan IA. Transient atrial mechanical dysfunction (stunning) after cardioversion of atrial fibrillation and flutter. Am Heart J, 2002; 144: 11-22.

22. Park SM, Kim YH, Choi JI, Pak HN, Kim YH, Shim WJ. Left atrial electromechanical conduction time can predict six-month maintenance of sinus rhythm after electrical cardioversion in persistent atrial fibrillation by Doppler tissue echocardiography. J Am Soc Echocardiogr, 2010; 23: 309-314.

23. Omi W, Nagai H, Takamura M et al. Doppler tissue analysis of atrial electromechanical coupling in paroxysmal atrial fibrillation J Am Soc Echocardiogr, 2005; 18: 39-44.

24. Acar G, Sayarlioğlu M, Akçay A et al. Evaluation of atrial electromechanical delay and LA mechanical functions in patients with rheumatoid arthritis. Turk Kardiyol Dern Ars, 2009; 37: 447-453.

25. Zapolski T, Wysokiński A. Stunning of the left atrium after pharmacological cardioversion of atrial fibrillation. Kardiol Pol, 2005; 63: 254-264.

26. Savontaus M, Markku M. Stunning of left atrial appendage after spontaneous conversion of atrial fibrillation. Echocardiography, 2008; 25: 340-341.

27. Agmon Y, Khandheria BK, Gentile F, Seward JB. Echocardiographic assessment of the left atrial appendage. J Am Coll Cardiol, 1999; 34: 1867-1877.

28. Marinigh R, Lip GY, Fiotti N, Giansante C, Lane D. Age as a risk factor for stroke in atrial fibrillation patients implications for thromboprophylaxis: Implications for thromboprophylaxis. J Am Coll Cardiol, 2010; 56: 827-837.

29. Friberg L, Rosenqvist M, Lip GY. Evaluation of risk stratification schemes for ischaemic stroke and bleeding in 182678 patients with atrial fibrillation: The Swedish Atrial Fibrillation cohort study. Eur Heart J, 2012; 33: 1500-1510. 